\title{
Analysis of the presence of cutaneous and mucosal papillomavirus types in ductal lavage fluid, milk and colostrum to evaluate its role in breast carcinogenesis
}

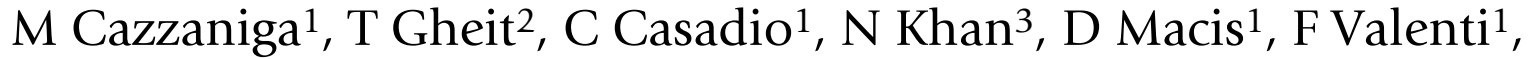 \\ MJ Miller ${ }^{1}$, BS Sylla ${ }^{2}$, S Akiba ${ }^{3}$, B Bonanni ${ }^{1}$, A Decensi ${ }^{4}$, U Veronesi ${ }^{1}$ and \\ M Tommasino*2
}

\author{
Address: ${ }^{1}$ European Institute of Oncology, Milan, Italy, ${ }^{2}$ International Agency for Research on Cancer, Lyon, France, ${ }^{3}$ Kagoshima University \\ Graduate School of Medical and Dental Sciences, Kagoshima, Japan and ${ }^{4}$ Ospedali Galliera, Genova, Italy \\ Email: M Tommasino* - tommasino@iarc.fr \\ * Corresponding author
}

from 6th International Symposium on the Intraductal Approach to Breast Cancer Santa Monica, CA, USA. |9-2| February 2009

Published: 24 July 2009

BMC Proceedings 2009, 3(Suppl 5):S5 doi:10.1186/1753-656I-3-S5-S5

This abstract is available from: http://www.biomedcentral.com/I753-656I/3/S5/S5

(c) 2009 Cazzaniga et al; licensee BioMed Central Ltd.

\section{Background}

The family of the epithelio-tropic human papillomavirus (HPV) comprises approximately 100 different types that have been subgrouped in different genera according to their genomic DNA sequence. In addition, the HPVs can be subdivided in mucosal and cutaneous based on their tissue tropism. Members of the genus alpha, referred to as mucosal high-risk HPV types, have been clearly linked to cervical cancer. Emerging lines of evidence indicate that another group of HPVs belonging to the genus beta may be involved in human carcinogenesis, i.e. non-melanoma skin cancer (NMSC). Several independent studies have suggested the involvement of mucosal HPV types in the aetiology of human breast cancer, while others have reported opposite findings. Here, we have analyzed the prevalence of alpha mucosal and beta cutaneous HPV types in 115 mammary fluids obtained by ductal lavages from 90 women at elevated risk for breast cancer as determined by the presence of viral DNA. We also analyzed a series of 25 colostrum and milk samples from women at average risk.

\section{Methods}

Different highly sensitive and specific polymerase chain reaction (PCR)-based protocols were used to detect DNA from mucosal and cutaneous HPV in ductal lavages (DL) obtained before $(n=70)$ or after removal of the superficial layer of the nipple epidermis by tape $(\mathrm{n}=45)$, as well as form colostrum $(\mathrm{n}=10)$ and milk $(\mathrm{n}=25)$.

\section{Results}

Ten of the 70 DLs analyzed (14\%) contained a single or multiple beta HPV type. Together, these 10 specimens contained 32 beta HPV DNAs. In contrast, DNA from mucosal high-risk HPV types was detected in only one sample $(1 / 70)$. From the 45 DL fluids collected after removal of the superficial layers of the nipple epidermis, the DNA of only two beta HPV types was found in two samples $(4 \%)$. In contrast, the epidermis of the nipple removed by the tape was strongly positive for beta cutaneous HPV types $(\approx 90 \%)$. All 115 DLs were negative for the mucosal low-risk HPV types 6 and 11. Finally, HPV positivity was low in colostrum and milk.

\section{Conclusion}

Our data show that DNA of alpha mucosa and beta cutaneous HPV types are rarely present in the breast fluids of high-risk women, and suggest that a direct role of HPV in breast carcinogenesis is unlikely. Ongoing studies are 
focused on the determination of other infectious agents in DL, e.g. EMV and/or MMTV.

Publish with Bio Med Central and every scientist can read your work free of charge

"BioMed Central will be the most significant development for disseminating the results of biomedical research in our lifetime. " Sir Paul Nurse, Cancer Research UK

Your research papers will be:

- available free of charge to the entire biomedical community

- peer reviewed and published immediately upon acceptance

- cited in PubMed and archived on PubMed Central

- yours - you keep the copyright

Submit your manuscript here:

http://www.biomedcentral.com/info/publishing_adv.asp 